\title{
BERGER, Sidney E. Rare Books and Special Collections. London: Facet.
} 2014. 552 pages. ISBN 978-1-78330-015-0. $£ 85.00$

The world of rare books and special collections librarianship is as varied as it is fascinating; covering everything from outreach and collection development to conservation and digitisation, those working in the field must have knowledge of a wide variety of areas to support special collections departments in the $21^{\text {st }}$ century.

Sidney E. Berger's book Rare Books and Special Collections examines the world of rare books and special collections in great depth to give newcomers an introduction to the subject and current practitioners a refresher course. Berger's work is impressive - the large volume spans 552 pages and 14 chapters. A text of this size seems intimidating at first; however, the book is beautifully presented: two columns of text on each page and a soft binding (which allows the book to lie flat) make reading easier. Illustrations and Berger's personal reflections throughout help to break text up into manageable sections.

Rare Books and Special Collections opens with a chapter summarising the practical realities of running a special collections department. The chapter provides an overview of issues faced by special collections librarians today, including the areas department managers should be informed about. Berger also introduces the reader to the two main groups supporting special collections work the RBMS (Rare Books and Manuscripts Section of the Association of College and Research Libraries) in the USA and CILIP's RBSCG (Rare Books and Special Collections Group) in the UK. The chapter is a useful starting point for early career professionals and also serves to establish Berger's main argument: special collections exist primarily to link users to the information they need to access.

Chapters 2 ('Running a Rare Book Department'), 5 - 8 ('Physical Layout and Operations', 'Fund-Raising', 'Security', 'Legal Issues'), 10 ('Book Collecting and Handling') and 11 ('Outreach') examine how to run a special collections department in depth. Each chapter outlines the issues facing special collections departments in each area and suggests possible approaches and solutions. Berger emphasises that knowing the collections in your department will assist librarians not only in improving users' experiences, but also in advocating the department's importance in the wider institution. Berger discusses issues in US and UK libraries throughout, which helps the reader gain a working knowledge of both countries. However, as Berger's focus and experience is primarily in special collections departments in America, UK based readers will need to look elsewhere for in depth discussions of certain topics - particularly legal issues and copyright.

Chapters 3 ('Archives'), 4 ('The Physical Materials of the Collection'), 9 ('Bibliography') and 12 ('Preservation, Conservation, Restoration and Disaster Planning') take a closer look at the knowledge needed to work with materials found in a special collections department, as well as the issues facing holdings in the $21^{\text {st }}$ century. Chapter 4 is especially strong, giving the reader a thorough insight into the physical makeup of the collection - including a history of 
materials used such as paper and ink. The chapter contains black and white photographs and illustrations to help the reader visualise the topics discussed. Chapters 4 and 12 are also the longest in the book ( 84 and 62 pages respectively), emphasising the importance of knowing how to care for material held in special collections.

The penultimate chapter (13, 'Special Collections Departments Today') examines the role of special collections departments in the $21^{\text {st }}$ century. In a world when librarians are faced with managing more information than ever before, do special collections departments still have a role to play? Berger argues strongly that yes, they do: technology, he believes "will enhance operations, not eliminate them" (Berger, 2014, 419). Berger discusses the role of digitisation, and states its continued importance as an "access medium" (Berger, 2014, 423) for researchers. Digitisation allows researchers across the globe to access collections online they previously may have ruled out visiting due to distance and it also helps to promote material held in special collections departments. However, Berger also notes that the "transition" from the analogue world to the digital world will only affect rare book and special collections departments in a "few narrow realms" (Berger, 2014, 449) due to the wide scope of activities undertaken. He notes that "there will always be a need and a desire for scholars to work with primary materials," (Berger, 2014, 441) and that special collections departments will always have an important institutional role in providing access to print collections.

Throughout the book, Berger gives the reader an insight into the issues he has faced during his career working with rare books and special collections. Each chapter contains personal reflections on the topic being discussed through examples of the problems he faced - and how he solved them. These sections are invaluable to the reader, particularly those of us new to the field - both in showing us what types of practical challenges we may encounter and how to put the theory discussed into practice. The book also makes the reader curious as to how far Berger's experiences are typical of rare books and special collections practitioners.

Rare Books and Special Collections is arguably Berger's masterpiece. The book is simultaneously a reference guide, a memoir and an instruction manual; it accomplishes all three aspects seamlessly. Most importantly, Berger reminds us why rare books and special collections is such an exciting field of librarianship to be working in today: it encompasses "everything" (Berger, 2014, 484). The breadth of knowledge and practical skills required mean that practitioners are constantly learning and developing through their own work, and will be for many years to come.

\section{Joanna Baines \\ Library Assistant \\ University of Sussex \\ J.C.Baines@sussex.ac.uk}

